\title{
Prochlorperazine Maleate
}

National Cancer Institute

\section{Source}

National Cancer Institute. Prochlorperazine Maleate. NCI Thesaurus. Code C775.

The maleate salt form of prochlorperazine, a synthetic, piperazine phenothiazine derivative with antiemetic, antipsychotic, antihistaminic, and anticholinergic activities. Prochlorperazine binds to and blocks the postsynaptic dopamine D2-receptor in the chemoreceptor trigger zone (CTZ) of the brain and may prevent chemotherapy-induced emesis. Prochlorperazine maleate also blocks anticholinergic and alpha-adrenergic receptors. Its antagonistic actions on the alpha- 1 adrenergic receptors results in sedation, muscle relaxation, and hypotension. 